\title{
The therapeutic outcomes and adverse drug reactions study of Clozapine on Schizophrenia inpatients in the Grhasia psychiatric hospital Yogyakarta, Indonesia
}

\author{
Woro Harjaningsih ${ }^{1}$, Laila Ayunirrahmah ${ }^{2}$,Nur Jannah Virsya Putri ${ }^{2}$ \\ ${ }^{1}$ Division of Pharmacology and Clinical Pharmacy, Faculty of Pharmacy, University of Gadjah Mada, Yogyakarta, Indonesia \\ ${ }^{2}$ Faculty of Pharmacy, University of Gadjah Mada, Yogyakarta, Indonesia
}

Keywords

Adverse drug reaction

Clozapine

Schizophrenia

Therapeutic outcome

\author{
Correspondence \\ Woro Harjaningsih \\ Division of Pharmacology and Clinical Pharmacy \\ Faculty of Pharmacy \\ University of Gadjah Mada \\ Yogyakarta \\ Indonesia \\ woro_yaning@ugm.ac.id
}

\begin{abstract}
Introduction: Clozapine is an antipsychotic agent used in schizophrenia recurrence or when other antipsychotics are not effective. Aims: This study aims to determine the therapeutic outcome and adverse drug reactions of clozapine in schizophrenia disorder among hospitalised patients. Methods: A retrospective cross-sectional study was conducted between January 2018 and December 2019 using inpatients' medical records from the Grhasia Psychiatric Hospital, Yogyakarta. The therapeutic outcome was measured with the PANSS-EC scale, while adverse drug reactions of clozapine were analysed theoretically as per the literature. Results: The average decrease in the PANSS-EC score was 8.27 , and the average duration to achieve this decrease was 2.5 days. The combination of typical-atypical antipsychotics could reduce the highest PANSS-EC score of 11-15 (41\%). The adverse drug reactions of clozapine were tremor, weight gain, obesity, leucopenia, hyperglycemia, and hypercholesterolemia, among other effects.

Conclusion: Clozapine is effective in improving positive and negative symptoms, but its use needs close monitoring.
\end{abstract}

\section{Introduction}

Schizophrenia is a mental disorder characterized by positive, negative, and cognitive symptoms, causing psychological, social, economic, and other problems in patients (Patel et al., 2014). Antipsychotic agents are the most used medications for relieving schizophrenia symptoms (Andreasen \& Black, 2006). They are classified as typical (first generation) and atypical (second generation) antipsychotics. Generally, the therapeutic outcome of antipsychotic agents is their potential effect to improve schizophrenia symptoms based on patients' characteristics. However, they may cause adverse drug reactions related to their mechanism of action (Chrismon \& Buckley, 2015).
Clozapine is an atypical antipsychotic agent used in schizophrenia recurrence or when other antipsychotics are not effective. It can be prescribed as monotherapy or combined with other antipsychotics and has many adverse drug reactions, ranging from mild to severe. Clozapine improves resistance to schizophrenia, but its use requires close and individual monitoring. Similar to other atypical antipsychotics, clozapine has adverse drug reactions, including weight gain, metabolic syndrome (major), and extrapyramidal syndrome (minor). It can also cause haematology disorders, such as neutropenia. In practice, the use of clozapine needs laboratory examination, particularly for long-term therapy. Previous studies reported that metabolic syndrome prevalence caused by clozapine was $50-60 \%$, occurring in patients who have no prior risk factors for this condition (Meyler, 
2016; Ventriglio et al., 2019). Clozapine also causes agranulocytosis in $1 \%$ of patients; this low prevalence is, however, dangerous and may lead to death (AphA, 2019). Furthermore, the risk for developing agranulocytosis can be detected as early as within the first three months of treatment (Alldredge et al., 2013). Several other lifethreatening adverse drug reactions are caused by clozapine, whether in the short or the long term use (Meyler, 2016), but data from Indonesia are still limited.

Based on these explanations and the scarcity of studies in Indonesia, updated research is essential to explore the therapeutic outcomes and adverse drug reactions of clozapine, particularly among the Indonesian population that presents many sociodemographic differences. It is noteworthy that the government policy in schizophrenia medication also contributes to the use of the drug.

Therefore, this study aimed to explore the therapeutic outcome and adverse drug reactions of clozapine among schizophrenia patients in the hospital setting.

\section{Methods}

\section{Study design}

This retrospective cross-sectional study was conducted between January 2018 and December 2019, using medical records of patients from the Inpatient Unit of the Grhasia Psychiatric Hospital, Yogyakarta. The data included patient characteristics, drug use patterns, therapeutic outcomes, and adverse drug reactions of clozapine.

Therapeutic outcome was measured with the PANSS-EC scale, while adverse drug reactions of clozapine were analysed theoretically using the Drug Information Handbook (2019) and Meyler's Side Effect of Drugs (2016). Data were analysed descriptively. The Positive and Negative Syndrome Scale (PANSS) is a tool that assesses positive and negative symptoms of schizophrenia and general psychopathology (Kay et al., 1987). The Positive and Negative Syndrome Scale-Excited Component (PANSS-EC), developed later by (Montoya et al., 2011), is one of the most simple-to-use and intuitive scales to assess agitated patients. The tool consists of five items exploring excitement, tension, hostility, uncooperativeness, and poor impulse control, rated from 1 (not present) to 7 (extremely severe). The score ranges from 5 to 35; mean scores equal to or higher than 20 clinically correspond to severe agitation (Montoya et al., 2011).

\section{Material}

Inclusion criteria were hospitalised patients who had been diagnosed with schizophrenia between January 2018 and December 2019 and taking clozapine as a monotherapy or combined therapy. Exclusion criteria were patients with incomplete or unclear data from their medical records. Data sampling used the purposive sampling method.

\section{Data analysis}

The data were analysed descriptively based on patients' characteristics, medication patterns, therapeutic outcomes, and adverse drug reactions.

\section{Results}

Table I describes patient characteristics, including age, gender, and occupation.

Table I: The characteristics of patients based on gender, age, and occupation

\begin{tabular}{lcc}
\hline Variable & Number of patients & Percentage (\%) \\
\hline Gender & 74 & 74 \\
Male & 26 & 26 \\
\hline Age (years old) & & \\
Male & 3 & 4 \\
$0-20$ & 52 & 72 \\
$21-50$ & 17 & 24 \\
$51-65$ & 0 & 0 \\
Female & 19 & 68 \\
$0-20$ & 9 & 32 \\
$21-50$ & & \\
$51-65$ & 27 & 27 \\
\hline Occupation & 73 & 100 \\
Employed & 100 & \\
Unemployed & & \\
\hline Total & & \\
\hline & & \\
\hline
\end{tabular}

The total number of participants was 100 patients, meeting the minimum sample size required. The results revealed more male patients than females ( $72 \%$ vs $28 \%$ ), to a previous study in The Psychiatric Hospital in Bali, Indonesia (Gemilang et al., 2017). No differences were found between male and female patients, although the new cases of schizophrenia were male patients (Ochoa et al., 2012).

Most patients were in the productive age between 21-50 years, with more males than females in this age bracket. This result is in line with previous findings showing a higher prevalence of adult patients. Theoretically, adults may experience schizophrenia symptoms due to their 
responsibilities and problems (Aryani \& Sari, 2016; Hariyanto et al., 2016).

The majority of patients were unemployed (73\%), similar to results from the Psychiatric Hospital in Central Sulawesi, Indonesia, reporting that $72 \%$ of patients were unemployed (Fahrul et al., 2014). Schizophrenia affects the cognitive function of patients, which contributes to difficulty in being hired in work and doing work well besides a negative stigma in the society because of the disorder (Drake, 2018).

\section{The medication pattern}

The medication pattern includes two phases: acute and stabilization. The acute phase is when the patient is carried to the emergency unit, while the stabilization phase is when the patient is moved to the bed site. The main difference between them is the targeted symptoms. The acute phase focuses on acute symptoms, while the stabilization phase focuses on relieving positive and negative symptoms and maintaining remission across the bed site.

Antipsychotics, whether typical or atypical, can be used alone or combined. Table II shows that combined therapy was used more than monotherapy. Theoretically, typical antipsychotics are effective in relieving positive symptoms but are similar to atypical antipsychotics in treating positive symptoms (Durand \& Barlow, 2007). The results also showed that atypical antipsychotics were used more than typical antipsychotics because they had other benefits, including better negative symptom relief and less risk of adverse drug reactions (Sadock et al., 2014; Ikawati, 2014).

Table II: The pattern of medication patterns

\begin{tabular}{|c|c|c|c|c|c|}
\hline Type of medication & $\begin{array}{l}\text { Type of } \\
\text { antipsychotics }\end{array}$ & Drug name & $\begin{array}{l}\text { Number } \\
\text { (cases) }\end{array}$ & $\%$ & $\begin{array}{l}\text { Total \% } \\
\text { category }\end{array}$ \\
\hline \multirow{3}{*}{ Monotherapy } & Typical & Haloperidol (inj.) & 2 & 1.7 & \multirow{3}{*}{5.9} \\
\hline & \multirow{2}{*}{ Atypical } & Clozapine & 2 & 1.7 & \\
\hline & & Risperidone & 3 & 2.5 & \\
\hline \multirow{11}{*}{$\begin{array}{l}\text { Combination of } 2 \\
\text { antipsychotics }\end{array}$} & \multirow{3}{*}{ Typical- Typical } & Haloperidol (tab.) + Chlorpromazine & 2 & 1.7 & \multirow{11}{*}{50} \\
\hline & & Haloperidol (tab.) + Chlorpromazine + Haloperidol (inj.) & 1 & 0.8 & \\
\hline & & Haloperidol (tab.) + Trifluoperazine & 1 & 0.8 & \\
\hline & Atypical- Atypical & Risperidone + Clozapine & 31 & 26.3 & \\
\hline & \multirow{7}{*}{ Atypical- Typical } & Clozapine + Haloperidol (tab.) & 10 & 8.5 & \\
\hline & & Clozapine + Haloperidol (inj.) & 2 & 1.7 & \\
\hline & & Clozapine + Haloperidol (tab.) + Haloperidol (inj.) & 4 & 3.4 & \\
\hline & & Risperidone + Chlorpromazine & 2 & 1.7 & \\
\hline & & Risperidone + Haloperidol (inj.) & 4 & 3.4 & \\
\hline & & Clozapine + Trifluoperazine & 1 & 0.8 & \\
\hline & & Risperidone + Trifluoperazine & 1 & 0.8 & \\
\hline \multirow{11}{*}{$\begin{array}{l}\text { Combination of } 3 \\
\text { antipsychotics }\end{array}$} & Typical- Typical & - & 0 & 0.0 & \multirow{11}{*}{43.2} \\
\hline & \multirow{2}{*}{ Atypical- Atypical } & Olanzapine (tab.) + Aripiprazole + Clozapine + Olanzapine (inj.) & 1 & 0.8 & \\
\hline & & Olanzapine (inj.) + Aripiprazole + Clozapine & 1 & 0.8 & \\
\hline & \multirow{8}{*}{ Typical- Atypical } & Risperidone + Clozapine + Haloperidol (tab.) & 5 & 4.2 & \\
\hline & & Risperidone + Clozapine + Haloperidol (inj.) & 29 & 24.6 & \\
\hline & & Risperidone + Clozapine + Haloperidol (tab.) + Haloperidol (inj.) & 9 & 7.6 & \\
\hline & & Olanzapine (tab.) + Risperidone + Chlorproazine & 1 & 0.8 & \\
\hline & & Risperidone + Chlorpromazine + Haloperidol (inj.) & 2 & 1.7 & \\
\hline & & Clozapine + Risperidone + Trifluoperazine + Haloperidol (tab.) & 1 & 0.8 & \\
\hline & & Aripiprazole + Clozapine + Haloperidol (inj.) & 1 & 0.8 & \\
\hline & & Clozapine + Fluphenazine (inj.) + Haloperidol (inj.) & 1 & 0.8 & \\
\hline \multirow{4}{*}{$\begin{array}{l}\text { Combination of } 4 \\
\text { antipsychotics }\end{array}$} & Typical-Atypical & Sulpiride + Clozapine + Risperidone + Haloperidol (inj.) & 1 & 0.8 & \multirow{4}{*}{0.8} \\
\hline & & Sulpiride + Clozapine + Risperidone + Haloperidol (inj.) & 1 & 0,5 & \\
\hline & & Sulpiride + Clozapine + Risperidone + Trifluoperazine & 1 & 0.5 & \\
\hline & & Clozapine + Olanzapine (tab.) + Risperidone + Chlorpromazine & 1 & 0.5 & \\
\hline Total & & & 198 & & 100 \\
\hline
\end{tabular}

\section{Therapeutic Outcomes}

Therapeutic outcomes were evaluated by assessing schizophrenia symptoms relief using the PANSS-EC scale. The pattern of decrease in PANSS-EC scores is listed in Table III. The average decrease in PANSS-EC scores was 8.27 days, and the average duration to achieve this decrease was 2.5 days. Table IV shows the pattern of decrease in PANSS-EC scores based on the types of antipsychotics used.
Based on Table IV, monotherapy with typical antipsychotics could decrease PANSS-EC scores by 6-10 points; haloperidol was highly effective in decreasing PANSS-EC scores, reaching 10 points (one patient). Combined typical-atypical antipsychotics could achieve the highest decrease (11-15 points) in PANSS-EC scores (41\%). Thus, the combination of different medications could relieve acute symptoms with an effective decrease in PANSS-EC scores. 
Table III: The patterns of the decreases in PANSS-EC score

\begin{tabular}{|c|c|c|c|c|}
\hline $\begin{array}{l}\text { Decrease in } \\
\text { PANSS-EC } \\
\text { score }\end{array}$ & Duration (days) & $\begin{array}{l}\text { Number } \\
\text { of } \\
\text { patients }\end{array}$ & $\%$ & $\begin{array}{l}\% \text { per } \\
\text { scale }\end{array}$ \\
\hline 0 & 1 & 1 & 1 & 1 \\
\hline \multirow{4}{*}{$1-5$} & 1 & 12 & 12 & \multirow{4}{*}{21} \\
\hline & 2 & 4 & 4 & \\
\hline & 3 & 2 & 2 & \\
\hline & 4 & 3 & 3 & \\
\hline \multirow{8}{*}{$6-10$} & 1 & 28 & 28 & \multirow{8}{*}{64} \\
\hline & 2 & 20 & 20 & \\
\hline & 3 & 4 & 4 & \\
\hline & 4 & 2 & 2 & \\
\hline & 5 & 3 & 3 & \\
\hline & 9 & 1 & 1 & \\
\hline & 12 & 1 & 1 & \\
\hline & 16 & 2 & 2 & \\
\hline \multirow{6}{*}{$11-15$} & 1 & 3 & 3 & \multirow{6}{*}{14} \\
\hline & 2 & 8 & 8 & \\
\hline & 4 & 1 & 1 & \\
\hline & 5 & 3 & 3 & \\
\hline & 8 & 1 & 1 & \\
\hline & 9 & 1 & 1 & \\
\hline Total & & 100 & 100 & 100 \\
\hline
\end{tabular}

The average of the decreases in PANSS-EC score is $\mathbf{8 . 2 7}$

The average of the durations of PANSS-EC score decrease (days) is $\mathbf{2 . 5}$

Table IV: The Patterns of the decreases in PANSS-EC score based on types of antipsychotics

\begin{tabular}{lccc}
\hline $\begin{array}{l}\text { The type of } \\
\text { antipsychotics }\end{array}$ & $\begin{array}{l}\text { Scale of the } \\
\text { decrease in } \\
\text { PANSS- EC score }\end{array}$ & $\begin{array}{c}\text { Number of } \\
\text { patients }\end{array}$ & \% \\
\hline Typical & $6-10$ & 1 & 1 \\
\hline Atypical & $1-5$ & 2 & 1 \\
\hline Typical-Typical & $11-15$ & 1 & 2 \\
\hline Atypical- & 0 & 1 & 1 \\
\hline Atypical & $1-10$ & 2 & 2 \\
\hline & $6-10$ & 7 & 7 \\
\hline Typical- & $11-15$ & 15 & 15 \\
\hline Atypical & $1-5$ & 5 & 5 \\
\hline Total & $11-15$ & 13 & 13 \\
\hline
\end{tabular}

Table $V$ presents the patterns of clinical symptom relief. Clinical symptoms included positive and negative symptoms in schizophrenia.

Table V: The patterns of clinical symptoms relief in the stabilisation phase

\begin{tabular}{|c|c|c|c|c|}
\hline \multicolumn{2}{|c|}{ Clinical symptoms } & \multirow{2}{*}{$\begin{array}{l}\text { Num } \\
\text { ber } \\
\text { (case } \\
\text { s) } \\
33\end{array}$} & \multirow{2}{*}{$\begin{array}{l}\% \text { of the } \\
\text { relieved } \\
\text { state (\%) }\end{array}$} & \multirow{2}{*}{$\begin{array}{l}\% \text { of } \\
\text { clinical } \\
\text { symptoms } \\
(\%)\end{array}$} \\
\hline \multirow{12}{*}{$\begin{array}{l}\text { Positive } \\
\text { symptoms }\end{array}$} & Delusion & & & \\
\hline & Relieved & 31 & 94 & 16.2 \\
\hline & Not relieved & 2 & 6 & \\
\hline & Hallucination & 46 & & \\
\hline & Relieved & 36 & 78 & 22.5 \\
\hline & Not relieved & 10 & 22 & \\
\hline & Poor impulse control & 15 & & \\
\hline & Relieved & 14 & 93 & 7.4 \\
\hline & Not Relieved & 1 & 7 & \\
\hline & Disorganised speech & 11 & & \\
\hline & Relieved & 9 & 82 & 5.4 \\
\hline & Not relieved & 2 & 18 & \\
\hline \multirow{15}{*}{$\begin{array}{l}\text { Negative } \\
\text { symptoms }\end{array}$} & Alogia & 65 & & \\
\hline & Relieved & 49 & 75 & 31.9 \\
\hline & Not relieved & 16 & 25 & \\
\hline & Blunted affect & 18 & & \\
\hline & Relieved & 18 & 100 & 8.8 \\
\hline & Not relieved & 0 & 0 & \\
\hline & Avolition & 6 & & \\
\hline & Relieved & 5 & 83 & 2.9 \\
\hline & Not Relieved & 1 & 17 & \\
\hline & Anhedonia/Asociality & 9 & & \\
\hline & Relieved & 8 & 89 & 4.4 \\
\hline & Not relieved & 1 & 11 & \\
\hline & Attention impairment & 1 & & \\
\hline & Relieved & 1 & 100 & 0.5 \\
\hline & Not relieved & 0 & 0 & \\
\hline Total & & 204 & & 100 \\
\hline
\end{tabular}

\section{Adverse drug reactions}

Adverse drug reactions in this study were determined by looking at SOAP (Subjective, Objective, Assessment, and Planning) notes and laboratory examination results in the medical records of hospitalised patients. The interpretation was based on the list of adverse drug reactions of clozapine in literature (Drug Information Handbook $17^{\text {th }}$ Edition and Meyler's Side Effects of Drugs $16^{\text {th }}$ Edition). The summary of adverse drug reactions is presented in Table VI. 
Table VI: The types of adverse drug reactions

\begin{tabular}{|c|c|c|}
\hline Adverse drug reaction & $\begin{array}{l}\text { Number of } \\
\text { patients } \\
(n=88)\end{array}$ & $\begin{array}{l}\text { Percentage } \\
(\%)\end{array}$ \\
\hline \multicolumn{3}{|l|}{ Cardiovascular } \\
\hline Hypotension & 6 & 6.8 \\
\hline Hypertension & 4 & 4.5 \\
\hline AV block & 1 & 1.1 \\
\hline \multicolumn{3}{|l|}{ Central Nervous System } \\
\hline Headache & 2 & 2.3 \\
\hline Insomnia & 1 & 1.1 \\
\hline \multicolumn{3}{|l|}{ Gastrointestinal } \\
\hline Nausea and vomitting & 6 & 6.8 \\
\hline Diarrhea & 3 & 3.4 \\
\hline Constipation & 2 & 2.3 \\
\hline \multicolumn{3}{|l|}{ Metabolism } \\
\hline Weight gain & 26 & 29.5 \\
\hline Hyperglycemia & 25 & 28.4 \\
\hline $\begin{array}{l}\text { Elevation in Blood } \\
\text { glucose level }\end{array}$ & 15 & 17.0 \\
\hline Hypercholesterolemia & 5 & 5.7 \\
\hline Obesity & 4 & 4.5 \\
\hline \multicolumn{3}{|l|}{ Hematology } \\
\hline Decrease in Leukocyte & 26 & 29.5 \\
\hline \multicolumn{3}{|l|}{$\begin{array}{l}\text { Decrease in ANC } \\
\text { (Absolute Neutrophil }\end{array}$} \\
\hline Count) & 23 & 26.1 \\
\hline Leukocytosis & 19 & 21.6 \\
\hline Elevation in leukocyte & 16 & 18.2 \\
\hline Leukopenia & 2 & 2.3 \\
\hline \multicolumn{3}{|l|}{ Muskuloskeletal } \\
\hline Tremor & 28 & 3.8 \\
\hline Lethargy & 4 & 4.5 \\
\hline Muscle rigidity & 3 & 3.4 \\
\hline Dystonia & 2 & 2.3 \\
\hline Dyskinesia & 1 & 1.1 \\
\hline Myalgia & 1 & 1.1 \\
\hline \multicolumn{3}{|l|}{ Others } \\
\hline Hypersalivation & 5 & 5.7 \\
\hline Diaphoresis & 1 & 1.1 \\
\hline
\end{tabular}

\section{Discussion}

Alongside a psychosocial rehabilitation program, antipsychotic agents are the drugs of choice to treat schizophrenia. Studies suggested that atypical antipsychotics resulted in better treatment retention and were more effective in preventing schizophrenia relapse than typical antipsychotics (Juleha et al., 2019).

In this study, combined therapy was preferred over monotherapy. The most used treatment was a combination of two antipsychotics $(50 \%)$, mainly risperidone + clozapine (26.3\%). According to Juleha and the authors (2019), risperidone is the most prescribed atypical antipsychotic (55\%). Among atypical antipsychotics, only risperidone and aripiprazole have evidence of efficacy and can be used as the first-line therapy in schizophrenia treatment (Dipiro et al., 2017). This study showed that clozapine was the most used medication in combination with risperidone. A previous study reported that clozapine (38\%) was the second most commonly prescribed atypical antipsychotic, in monotherapy or combined with other antipsychotics, to treat schizophrenia resistance (Juleha et al., 2019). Clozapine showed to be superior in managing treatment-resistant schizophrenia or among patients with suicide risk (Dipiro et al., 2017). Schizophrenia therapeutic guidelines recommend clozapine or combined antipsychotics but prefer clozapine as monotherapy in patients with refractory schizophrenia (Buchanan et al., 2010).

In the study, the second most prescribed treatment was a combination of three antipsychotics (43.2\%), i.e., risperidone + clozapine + haloperidol (injection) (24.6\%). Haloperidol is used to treat positive symptoms mainly (Kay \& Singh, 1989). Similarly, Indriani and the authors (2019) had found that this combination was the most used in schizophrenia patients (risperidone + clozapine + haloperidol).

Schizophrenia presents with one or more of the following signs: delusions, hallucinations, disturbed thinking and talking, behavioural disorders, and negative symptoms. Treatment effectiveness is measured with instruments, such as the PANSS-EC (Patel et al., 2014). The results showed that the average decrease in the PANSS-EC score was 8.27 , and the average duration to achieve this decrease was 2.5 days. Similarly, a study conducted by Ayuningtyas and the authors (2018) in Prof. Dr. Soerojo Psychiatric Hospital, Magelang, Indonesia, reported that clozapine significantly decreased PANSS-EC scores as monotherapy or in combination, using post hoc ANOVA $(p=0.05)$. This study also showed that combined typical-atypical therapy resulted in the highest PANSS-EC scores decrease (11-15, $41 \%)$. It also revealed that a combination of different medications improved acute symptoms and lowered PANSS-EC scores.

In this study, $78 \%$ of patients showed improvement in hallucination after taking their medication. Moreover, the most common negative symptom in the study was 
alogia (31.9\%), with $75 \%$ of patients showing relief. According to a previous study, the mean differences of the PANSS subgroups were more significant in the clozapine group than in the typical agents' group, which were in decreasing order: general psychopathology, anergia, positive, and negative symptoms. In the typical group, signs were (in decreasing order): general psychopathology, positive, and negative symptoms. This finding showed that both treatments (typical and atypical groups) improved positive symptoms more than negative symptoms (Sharafi, 2005). Some studies found that the efficacy of clozapine is clinically significant on negative symptoms but is delayed compared to its efficacy on other symptoms evaluated by the PANSS. Hence, both positive and negative symptoms appear to be improved with clozapine. Additionally, research suggests that the improvement of negative symptoms is directly related to positive symptoms after clozapine therapy (Sharafi, 2005).

Combined therapy involving clozapine can result in increased adverse drug reactions. The most commonly reported were tremor (28 patients), weight gain (26 patients), leukocytopenia (26 patients), and hyperglycemia (25 patients), as well as other adverse drug reactions.

\section{Cardiovascular effects}

Adverse drug events related to the cardiovascular system included hypotension (6 patients), hypertension (4 patients), and atrioventricular (AV) block (1 patient). The mechanism of clozapine-induced hypertension was assumed to be caused by alfa-2 adrenoceptors blockade (Meyler, 2016). Furthermore, hypotension is an adverse drug reaction commonly found in patients taking clozapine, as $9 \%$ of these patients might experience orthostatic hypotension (De Berardis et al., 2018). It usually occurs as early as within the first 4-6 weeks of treatment; this effect can be tolerated by patients (Iqbal et al., 2003). Paradoxically, cardiovascular effects such as tachycardia are not uncommon in patients using clozapine, often leading to palpitations (Yuen et al., 2018).

\section{Central nervous system effect}

This effect involved insomnia (1 patient) and headache (2 patients). According to Drug Information Handbook $17^{\text {th }}$ Edition, clozapine can cause headaches with a prevalence of $7 \%$ (AphA, 2019). The low number of patients with headaches in this study could be likely because physicians did not report it in the medical record.

\section{Gastrointestinal effects}

In this study, gastrointestinal effects included nausea- vomiting (6 patients), diarrhoea (3 patients), and constipation ( 2 patients). Constipation incidence of clozapine was 14-25\% (AphA, 2019). The results of this study were similar to the theory, where the prevalence of anticholinergic symptoms (including constipation) was $20 \%$ as clozapine is a strong M1 muscarinic antagonist (Alldredge et al., 2013; Meyler, 2016). Also, nausea prevalence was $11 \%$ in patients taking clozapine. This effect was due to the anticholinergic activity of clozapine, causing a delay of transit time in the gastrointestinal tract, a decrease in diet intake, and a direct effect on the hypothalamus (Iqbal et al., 2003).

\section{Metabolism effect}

Metabolism effects included weight gain (26 patients), hyperglycemia (25 patients), elevation in blood glucose levels (15 patients), hypercholesterolemia (5 patients), and obesity (4 patients). Metabolic syndrome was determined by laboratory examination results. Most examinations were done one time only upon admission but could be carried out more than once in patients with some comorbidities. Obesity was found in all patients. Previous studies concluded that clozapine affected weight gain significantly in patients taking clozapine compared to controls (Rummel-Kluge et al., 2010; Dayabandara et al., 2017). The relation between dose and weight gain was not clear. The results of a study among 50 schizophrenia patients using 100, 300, or $600 \mathrm{mg} /$ day of clozapine over four months showed that the increase in doses was linear with the weight gain of patients. Patients gained as much as $4.4 \mathrm{~kg}$ at $600 \mathrm{mg}$ dose, $2.6 \mathrm{~kg}$ at $300 \mathrm{mg}$ dose, and $1.3 \mathrm{~kg}$ at 100 mg dose (Meyler, 2016).

There was no standard related to weight gain due to clozapine, with patients showing varying results. This condition is assumed to be caused by the relation between weight gain and the serotonin polymorphism system (De Luca et al., 2007; Sicard et al., 2010).

\section{Hyperglycemia}

Of the total sample, four patients had abnormal fasting blood glucose levels, likely caused by medications and history limitations. Further studies are necessary to examine the effects of clozapine on blood glucose levels. Besides, these patients had been diagnosed with schizophrenia for 6-18 years, which might indirectly increase blood glucose levels. Other contributing factors included patients' behaviour, diet, and physical activities that could affect the metabolism.

The results of this study showed that clozapine use (whether acute or chronic) was related to insulin sensitivity, high blood glucose levels, and low insulin plasma levels, reflected by decreased insulin secretion (Liu et al., 2017). A previous study reported increased 
blood glucose levels with an average clozapine dose of $362 \mathrm{mg} /$ day. The prevalence of metabolic syndrome caused by clozapine was $60 \%$ with a dosage of 615 $\mathrm{mg} / \mathrm{day}$, and there was no significant correlation between metabolic syndrome prevalence and clozapine dosage, which found that metabolic syndrome prevalence was $51.9 \%$ (Vancampfort et al., 2013; Ventriglio et al., 2019). Age, medication duration, and length of schizophrenia also contributed to metabolic syndrome.

\section{Hypercholesterolemia effects}

In this study, cholesterol laboratory examination was done in only 23 patients, and this examination was also only one time for each patient. Among them, five patients had abnormal cholesterol levels. All five patients had used clozapine for more than three years. The schizophrenia patient tended to have a high appetite and limited physical activity so that they increased weight gain potency causing metabolic syndrome like dyslipidemia. It needs lipid level monitoring mainly when atypical antipsychotics started, and it is carried out in the early medication, 12 weeks after treatment, and every five years during medication (Alldredge et al., 2013).

\section{Haematology effects}

Adverse drug reactions related to haematology effects included a decrease in leukocyte (26 patients), absolute neutrophil count (23 patients), leukocytosis (19 patients), and increase in leukocyte (16 patients) as well as leukopenia (2 patients).

There is no explanation about the correlation between leucopenia or agranulocytosis risk and dosage of clozapine, but several case reports confirm agranulocytosis cases appearing in the patients taking clozapine at doses of $500 \mathrm{mg} /$ day. This effect is reversible when clozapine is discontinued (Meyler, 2016). For that reason, leucocyte laboratory examination must be done before and during treatment, with clozapine monitoring every two weeks in the second 6 months of treatment, then every month during clozapine use. If leukocyte count is less than 2000 cells $/ \mathrm{mm}^{3}$, then clozapine treatment must stop until leukocyte is normal (Crismon et al., 2015).

\section{Musculoskeletal effects}

The most common adverse drug reaction was tremor (28 patients), one of the clinical manifestations of extrapyramidal syndrome. Atypical antipsychotics have minimum extrapyramidal effects compared to typical antipsychotics. The reported tremor prevalence caused by clozapine was only 6\% (AphA, 2019). Two patients using clozapine monotherapy had tremors. They had been taking clozapine for 2 and 5 years, respectively. Tremors occurred most frequently in patients using the combination clozapine + risperidone. This effect is related to the receptor affinity, and clozapine has a weaker binding with the D2 receptor than risperidone; thus, risperidone is more likely to cause extrapyramidal syndrome (Divac et al., 2014).

\section{Other effects}

Other adverse drug reactions appeared in the study, i.e. hypersalivation ( 5 patients) and diaphoresis (1 patient). Hypersalivation is a common effect of clozapine, with an incidence rate of $10-23 \%$. In this study, hypersalivation was most commonly detected among patients taking clozapine at a dose of $100 \mathrm{mg} /$ day; this effect also occurred at doses lower than $25 \mathrm{mg} /$ day. Theoretically, hypersalivation is dosage-dependent. The higher the dosage of clozapine, the higher the hypersalivation. The mechanism of hypersalivation is a decrease in larynx peristalsis due to muscarinic (M4) receptor agonists and alfa-2 receptor antagonists (Meyler, 2016).

These adverse drug reactions generally occur within the first months of treatment, prompting patients to withdraw from the medication. Often the main reason for discontinuing clozapine treatment is its intolerable adverse drug reactions. Hence, it is essential to manage adverse drug reactions adequately to maintain therapeutic outcomes. Dose adjustment can considerably help in minimizing the occurrence of adverse drug reactions. Usually, patients who have frequent but non-severe adverse drug reactions, such as increased appetite, sedation, enuresis, or hypersalivation, do not require adjustment (reduced doses) or drug intervention. Nevertheless, it is always recommended that routine assessment and blood monitoring be carried out before and after the initiation of clozapine to prevent severe adverse drug reactions (Pharmaceutical Services Programme, 2018).

This study has several limitations. First, most patients took combined therapy; thus, adverse drug reactions could be due to either antipsychotic. Second, the researchers interpreted the patient symptoms during inpatient care based on the literature. Third, this study could not determine a causal relationship and other factors related to adverse drug reactions in clozapinetreated patients. Furthermore, some assumptions and interpretations were made as the description of adverse drug reactions was not written clearly in the medical records.

Further prospective studies taking into account these limitations are necessary to confirm the results of this study. 


\section{Conclusion}

The average decrease in the PANSS-EC score was 8.27, and the average duration needed to achieve this decrease was 2.5 days. The combination of typicalatypical antipsychotics could reduce the highest PANSS-EC score of $11-15$ (41\%). In this study, $78 \%$ of patients showed improvement in hallucination after taking their medication. Moreover, the most common negative symptom in the study was alogia (31.9\%), with $75 \%$ of patients showing relief.

Adverse drug reactions of clozapine were tremor (28 patients; 31.8\%), weight gain (26 patients; $29.5 \%$ ), obesity (4 patients; $4.5 \%$ ), leukopenia (26 patients; $29.5 \%$ ), hyperglycemia (25 patients; $28.4 \%$ ), elevation in blood glucose levels (15 patients; 17.0\%), and hypercholesterolemia (5 patients; $5.7 \%$ ), in addition hypersalivation, diaphoresis, and cardiovascular, central nervous system, hemotology, and musculoskeletal effects.

\section{Acknowledgements}

The authors acknowledge the head and all staff of the Grhasia Psychiatric Hospital Yogyakarta, Indonesia, for providing support and facilitating the data collection.

\section{References:}

Andreasen, N.C., \& Black, D. W., (2006), Introductory Textbook of Psychiatry, USA: American Psychiatric Association Publishing

Aryani, F., \& Sari, O., (2016), Gambaran Pola Penggunaan Antipsikotik Pada PasienSkizofrenia Di Ruang Rawat Inap Rumah Sakit Jiwa, Jurnal Manajemen dan Pelayanan Farmasi, 6 (1), 35-40. https://doi.org/10.22146/jmpf.236

Alldredge, B.K., Affairs, A., Francisco, S., Francisco, S., Corelli, R.L., Francisco, S., Francisco, S., Ernst, M.E., City, I., Guglielmo, B.J., Francisco, S., Francisco, S., Jacobson, P.A., Pharmacology, C., Kradjan, W.A., Emeritus, D., Health, O., Williams, B.R., Gerontology, C \&Economics, P.,(10th Ed). (2013), Applied therapeutics: The clinical use of drugs, Philadelphia: Lippincott Williams \& Wilkins

AphA., (21th Ed). (2019), Drug Information Handbook, Ohio: Lexicomp

Buchanan. R.W., Kreyenbuhl, J., Kelly, D.L., Noel, J.M., Boggs, D.L., \& Fischer, B.A., (2010), The 2009 schizophrenia PORT psychopharmacological treatment recommendations and summary statements. Schizophrenia Bulletin, 36, 71-93

Crismon, M.L., Argo, T.R., \& Buckley, P.F., (9th Ed). (2015), Schizophrenia, Pharmacotherapy Handbook, USA: McGraw Hill Company
Dayabandara, M., Hanwella, R., Ratnatunga, S., Seneviratne, S., Suraweera, C. \& de Silva, V.A, (2017), Antipsychoticassociated weight gain : management strategies and impact on treatment adherence, Neuropsychiatric Disease and Treatment, 2231-2241

De Luca, V., Mueller, D.J., de Bartolomeis, A. \& Kennedy, J.L, (2007), Association of the HTR2C gene and antipsychoticinduced weight gain: a meta-analysis, International Journal Neuropsychopharmacol, 10: 697-704

Dipiro, J.T., Talbert, R.L., Yee, G.C., Matzke, G.R., Wells, B.G., \& Posey, L.M., (9 th Ed). (2017), Pharmacotherapy: a pathophysiologic approach, New York: Mc Graw-Hill Medical Publishing Division

De Berardis, D., Gabriella, R., \& Olivieri, L., (2018), Safety of antipsychotics for the treatment of schizophrenia: a focus on the adverse effects of clozapine, Therapeutic Advances in Drug Safety, 9(6): 237-256

Divac, N., Prostran, M., Jakovcevski, I. \& Cerovac, N, (2014), Extrapyramidal Adverse Effects, Biomed Res Int. https://doi.org/10.1155/2014/656370

Drake, E.R., (2018), Employment and Schizophrenia: Three Innovative Research Approaches, Schizophrenia Bulletin, $\mathbf{4 4}$ (1), https://doi.org/10.1093/schbul/sbx170

Durand, V.M., \& Barlow, D.H., (4th Ed). (2007), Intisari Psikologi Abnormal, Yogyakarta: Terjemahan Pustaka Pelajar

Fahrul, F., Mukaddas, A., \& Faustine, I., (2014), Rasionalitas Penggunaan Antipsikotik pada Pasien Skizofrenia di Instalasi Rawat Inap Jiwa RSD Madani Provinsi Sulawesi Tengah Periode Januari-April 2014, Online Journal of Natural Science, 3 (2), 18-29. Available at: http://jurnal.untad.ac.id/jurnal/index.php/ejurnalfmipa/arti cle/view/2981

Gemilang, B.M., Lesmana, C.B.J., \& Aryani, L.N.A., (2017), Karakteristik Pasien Relapse pada Pasien Skizofreniadan Faktor Pencetusnya di Rumah Sakit Jiwa (RSJ)Provinsi Bali, $E$ Jurnal Medika, 6 (10), 61-65. Available at: http://ojs.unud.ac.id/index.php/eum

Hariyanto, I., Putri, R.A., \& Untari, E.K., (2016), Perbedaan Jenis Terapi Antipsikotik terhadap Lama Rawat Inap PasienSkizofrenia Fase Akut di RSJD Sungai Bangkong Pontianak, Jurnal Farmasi Klinik Indonesia, 5 (2), 115-122. https://doi.org/10.15416/ijcp.2016.5.2.115

Ikawati, Z., (2014), Farmakoterapi Sistem Saraf Pusat, Yogyakarta: Bursa Ilmu

Indriani, A., Ardiningrum, W., \& Febrianti, Y., (2019), Studi Penggunaan Kombinasi Antipsikotik pada Pasien Skizofrenia di Rumah Sakit Yogyakarta, Majalah Farmasetika, 4(1), 201 211. https://doi.org/10.24198/mfarmasetika.v4i0.25882

Iqbal, M.M., Rahman, A., Husain, Z., Mahmud, S.Z., Ryan, W.G. \& Feldman, J.M, (2003), Clozapine : A Clinical Review of Adverse Effects, Ann Clin Psychiatry,15(1): 33-48. https://doi.org/10.1023/a:1023228626309

Juleha, J., Athiyah, U., \& Hermansyah A., (2019), The prescription patterns of second-generation antipsychotics in schizophrenia outpatient setting, Journal of Basic and Clinical 
Physiology and Pharmacology.
and https://doi.org/10.1515/jbcpp-2019-0289

Kay, S.R., Fiszbein, A., \& Opler, L.A. (1987). The positive and negative syndrome scale (PANSS) for schizophrenia. Schizophrenia Bulletin 13, 261-276

Kay, S.R., \& Singh, M.M., (1989). The Positive \& Negative Distinction in drug free schizophrenia patients, Arch Gen Psychiatry, 46 (8), p 711-718

Liu, X., Wu, Z., Lian, J., Hu, C.H., Huang, X.F. \& Deng, C. (2017). Time-dependent changes and potential mechanisms of glucose-lipid metabolic disorders associated with chronic clozapine or olanzapine treatment in rats, Scientific Reports, 7(1): 1-13

Meyler, L., (16th Ed). (2016), Meyler's Side Effects of Drugs, Oxford, UK: Elsevier

Montoya A, Valladares A, Lizan L, San L, Escobar R, \& Pan S, (2011). Validation of the Excited Component of the Positive and Negative Syndrome Scale (PANSS-EC) in a Naturalistic Psychosis and Agitation in a Psychiatric Emergency Room. Health Qual Life Outcomes, 29 (9). 18. https://doi.org/10.1186/1477-7525-9-18

Ochoa, S., Usall, J., Cobo, J., Labad, X., \& Kulkarni, J. (2012). Gender Differences in Schizophrenia and First-Episode Psychosis: A Comprehensive Literature Review, Schizophrenia Research and Treatment

Patel, K.R., Cherian, J., Gohil, K., \& Atkinson, D., (2014), Schizophrenia: Overview and Treatment Options, Journal of Pharmacy \& Therapeutics. 39 (9), 638-645

Pharmaceutical Services Programme. (2018). Adverse Drug Reactions of Clozapine and Their Management in a Tertiary Care Hospital in Kelantan, Pharmacy Research Reports, 1, Ministry of Health Malaysia

Rummel-Kluge, C., Komossa, K., Schwarz, S., Hunger, H., Schmid, F., Lobos, C.A., Kissling, W., Davis, J.M. \& Leucht, S. (2010). Head-to-head comparisons of metabolic side effects of second generation antipsychotics in the treatment of schizophrenia: A systematic review and meta-analysis. Schizophrenia Research, 123(2-3): 225-233

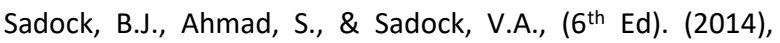
Kaplan \& Sadock's Pocket Handbook of Psychiatric Drug Treatment, USA: Lippincott William \& Wilkins

Sharafi, M. (2005). Comparison of Classical and Clozapine Treatment on Schizophrenia Using Positive and Negative Syndrome Scale of Schizophrenia (PANSS) and SPECT Imaging. International Journal of Medical Sciences, 2(2):7986

Sicard, M.., Zai, C.C., Tiwari, A.K., Souza, R.., Meltzer, H.Y., Lieberman, D.J., Kennedy, J.L. \& Muller, D.J. (2010). Polymorphisms of the HTR2C gene and antipsychoticinduced weight gain: an update and meta-analysis. Pharmacogenomics, 11: 1561-1571

Vancampfort, D., Sweers, K., Winkel, R. Van, Yu, W. \& Hert, M. De. (2013). Prevalence of Metabolic Syndrome and Metabolic Abnormalities in Schizophrenia and Related Disorders. A Systematic Review and Meta-Analysis, 39(2): 306-318
Ventriglio, A., Baldessarini, R.J., Vitrani, G., Bonfitto, I., Cecere, A.C., Rinaldi, A., Petito, A. \& Bellomo, A,. (2019), Metabolic Syndrome in Psychotic Disorder Patients Treated With Oral and Long-Acting Injected Antipsychotics

Yuen, J.W.Y., Kim, D.D., Procyshyn, R.M., White, R.F., Honer, W.G., \& Barr, A. M.. (2018). Clozapine-Induced Cardiovascular Side Effect and Autonomic Dysfunction. $A$ Systematic Review, Frontiers in Neuroscience. https://doi.org/10.3389/fnins.2018.00203 